\title{
Effect of Glycaemic Control on Thyroid Hormones Level in Type 2 Diabetic Patients
}

\author{
Alo K ${ }^{1 *}$, Begum Mahmuda ${ }^{2}$, Rahman $\mathrm{MM}^{3}$ \\ ${ }^{1}$ Department of Physiology, Khwaja Younus Ali Medical College, Enayetpur, Sirajganj, \\ Bangladesh; ${ }^{2}$ Department of Physiology, Sir Salimullah Medical College, Dhaka, Bangladesh; \\ ${ }^{3}$ Department of Community Medicine, Anwar Khan Modern Medical College, Dhaka, Bangladesh
}

\begin{abstract}
Background: Thyroid dysfunction, a common endocrine disorder that increasing day by day. Hypothyroidism occasionally occurs in diabetic patients especially those with poor glycaemic control.

Objectives: The objective of the study was to observe the effect of glycaemic control on thyroid hormones level in type 2 diabetic patients and to determine selected socio-demographic characteristics of the respondents.

Methods: This case control study was carried out in the Department of Physiology, Sir Salimullah Medical College (SSMC), Dhaka from July 2016 to June 2017. A total of sixty subjects of both male and female, age ranged from 40 to 60 years were included in this study. Among them, thirty were type 2 diabetic patients (both uncontrolled and controlled) and another thirty were included for comparison as control and were matched by age, sex, and body mass index (BMI). Both case and control group were selected purposively based on selection criteria. Serum TSH, $\mathrm{FT}_{4}$ and $\mathrm{FT}_{3}$ levels were measured by chemiluminescent micro particle immunoassay (CMIA) method. Fasting blood glucose level was estimated by glucose oxidase (GOD) method and blood $\mathrm{HbA}_{1 \mathrm{c}}$ level was estimated by ion exchange high performance liquid chromatography (HPLC) method. The statistical analysis was done by ANOVA test, Bonferroni test and Pearson's correlation coefficient test. Quality control of data was maintained by using a checklist.
\end{abstract}

Results: In this study, mean serum TSH level was significantly higher in uncontrolled diabetic patients than that of controlled diabetic patients. Serum $\mathrm{FT}_{4}$ level was significantly lower in uncontrolled diabetic patients in comparison to that of controlled diabetic patients. Besides these, serum TSH level was positively correlated $(\mathrm{r}=+0.575)$, serum $\mathrm{FT}_{4}$ and $\mathrm{FT}_{3}$ levels were negatively correlated $(\mathrm{r}=-0.588, \mathrm{r}=-$ $0.527)$ with $\mathrm{HbA}_{\mathrm{Ic}}$ level in uncontrolled diabetic patients and all these relationships were statistically significant $p \leq 0.05$ respectively.

Conclusion: The present study revealed that hypothyroidism occurs in type 2 diabetic patients which were found only in uncontrolled diabetic patients due to their poor glycaemic control.

Keywords: Thyroid stimulating hormone, Free thyroxine, Free triiodothyronine, Glycaemic control.

\section{Introduction}

Diabetes is characterized by chronic hyperglycemia associated with disturbances in protein and lipid metabolism on account of absolute or relative deficiency or inefficiency of insulin. ${ }^{1}$ The reduced sensitivity to insulin is often called insulin resistance. $^{2}$ The prevalence of diabetes mellitus is increasing throughout the world due to population growth, aging, urbanization, increase prevalence of obesity and physical inactivity and increased consumption of refined foods globally., ${ }^{3,4}$ Long term diabetes mellitus is associated with vascular complications like retinopathy, nephropathy, peripheral and autonomic neuropathy,

*Correspondence: Dr. Kamrunnahar Alo, Department of Physiology, Khwaja Younus Ali Medical College, Sirajganj, Bangladesh;

e-mail: aloalo0308@gmail.com; ORCID: 0000-0002-8870-0495 cardiovascular and cerebrovascular diseases but adequate glycemic control can delay development of diabetic complication. ${ }^{5,6}$

Thyroid dysfunction is another common endocrine disorder that is also increasing day by day and manifests either as hyper or hypothyroidism that may occur in type 2 diabetic patients. $^{7,8}$ There is great variability in the prevalence of thyroid dysfunction in general population ranging from $6.6 \%$ to $13.4 \%$ where as in diabetic patients the prevalence is greater and varies from 10 to $24.0 \% .{ }^{9}$ This difference can be explained by different diagnostic criteria of thyroid disease, the degree of iodine intake among different regions, different sensitivities of the TSH assays and the large population diversity. ${ }^{10}$ However, in type 2 diabetic patients 
hypothyroidism is more common than hyperthyroidism. ${ }^{11}$ Some researchers observed that $28.8 \%$ of diabetic patients having abnormal thyroid hormone levels, $22.5 \%$ had hypothyroidism and $6.3 \%$ had hyperthyroidism. ${ }^{12}$ In this country, another researcher found $16.3 \%$ thyroid dysfunction among type 2 diabetic patients $(9.0 \%$ had hypothyroidism and $7.0 \%$ had hyperthyroidism). ${ }^{13}$ Diabetes mellitus influence thyroid function mainly at two sites; first at the level of hypothalamic control of thyroid stimulating hormone release and second, at the conversion of $\mathrm{T}_{4}$ to $\mathrm{T}_{3}{ }^{14}$ especially those with poor glycaemic control. ${ }^{14,15}$ Bartalena et al found that poor glycemic control affects the hypothalamopituitary-thyroid axis. ${ }^{16}$ It causes impairment of nocturnal TSH secretion, thyroid hormone secretion and their response to TRH stimulation. ${ }^{17}$ On the other hand, higher circulating level of insulin associated with insulin resistance causes proliferation of thyroid tissue and formation of thyroid nodules. ${ }^{18}$ Moreover, alteration of the secretory activities of thyroid gland causes low thyroid hormone level. ${ }^{19}$ Uncontrolled diabetes is also associated with low serum $\mathrm{T}_{3}$ state and impaired production of $T_{3}$ from $T_{4}$. Because the activity of thiol dependent hepatic enzyme $\mathrm{T}_{4}$ - 5 deiodinase that causes peripheral conversion of thyroxin to triiodothironine via 5 monodeiodination reaction is reduced. ${ }^{20}$ Besides these, Sahu et al reported that thyroid peroxidase antibody is responsible for thyroid dysfunction in type 2 diabetic patients. ${ }^{21}$

The relationship between thyroid disorders and type 2 diabetes mellitus is characterized by a complex interdependent interaction. The prevalence of thyroid disorders in type 2 diabetic patients which is further found to be more in uncontrolled diabetic patients. ${ }^{22}$ Some researchers suggested that, type 2 diabetic patients should measure serum TSH level yearly to detect asymptomatic thyroid dysfunction as it may help to achieve good glycemic control. ${ }^{23,24}$ Otherwise, it can aggravate classical risk factors such as dyslipidaemia and lead to an increased risk of cardiovascular events and nephropathy in these patients. ${ }^{6,25}$

\section{Materials and Methods}

This case control study was conducted among 30 diagnosed type 2 diabetic patients age ranged from 40 to 60 years were selected from the Out Patient Department of Endocrinology, Sir Salimullah Medical College (SSMC) and
Mitford Hospital, Dhaka. The patients were diagnosed according to American Diabetic Association (ADA) criteria. Thirty apparently healthy subjects with similar age, BMI and socioeconomic status were selected as comparison/Control (Group A). Study group was again subdivided into two groups. Group $\mathrm{B}_{1}$ included 17 uncontrolled diabetic patients and Group $\mathrm{B}_{2}$ included 13 controlled diabetic patients. Both control and study groups were selected purposively. The study protocol was approved by Institutional Ethics Committee of SSMC. Diabetic patients with renal disease, known thyroid abnormalities, any other endocrine abnormalities and pregnancy were excluded from this study. After selection, the subjects were thoroughly informed about the aim, objectives and procedure of the study and were encouraged for voluntary participation. An informed written consent was taken from each subject. Data were generated using a standard pre-tested questionnaire. It was filled up by the principal investigator individually. In addition, samples were collected by the principal investigator as well. With all aseptic precautions $7 \mathrm{ml}$ of venous blood was drawn by sterile disposable syringe from ante-cubital vein. Then $2 \mathrm{ml}$ of whole blood was transferred to an EDTA tube for determination of $\mathrm{HbA}_{1 \mathrm{c}}$ level. The remaining blood was transferred to a clean and dry glass test tube and was kept in slanted position till formation of clot. After centrifugation, supernatant serum was collected in labeled eppendroff test-tube and was used for different biochemical tests. In assessing thyroid function, serum $\mathrm{TSH}, \mathrm{FT}_{4}$ and $\mathrm{FT}_{3}$ levels were measured by chemiluminescent microparticle immunoassay (CMIA) method in the Department of Biochemistry, BSMMU, Dhaka however, fasting plasma glucose level was estimated by glucose oxidase (GOD) method in the Department of Physiology, SSMC and $\mathrm{HbA}_{\mathrm{lc}}$ levels were estimated by ion exchange high performance liquid chromatography (HPLC) method in the Department of Biochemistry, BSMMU to observe participants glycemic status. Correlation of $\mathrm{HbA}_{1 \mathrm{c}}$ with serum $\mathrm{TSH}, \mathrm{FT}_{4}$ and $\mathrm{FT}_{3}$ were done to observe its relationship. The data quality control was done using appropriate checklist. The statistical analysis was done by ANOVA test, Bonferroni test and Pearson's correlation coefficient test by using Statistical Package of Social Science (SPSS) windows. The ethical clearance was obtained from the Institutional Review Board of the Sir Salimullah Medical College (SSMC), Dhaka. 


\section{Results}

In this study, the mean fasting blood glucose level was significantly $(p<0.001, p \leq 0.05)$ higher in uncontrolled and controlled diabetic patients in comparison to that of non-diabetic subjects and it was also significantly $(p<0.001)$ higher in uncontrolled diabetic patients in comparison to that of controlled diabetic patients. Again, the mean $\mathrm{HbA}_{1 \mathrm{c}}$ level was significantly $(p<0.001$, $p<0.01)$ higher in uncontrolled and controlled diabetic patients in comparison to that of nondiabetic subjects and it was also significantly $(p<0.001)$ higher in uncontrolled diabetic patients than that of controlled diabetic patients (table II).

Table I: Age, body weight \& BMI in both groups $(n=60)$

\begin{tabular}{ccccc}
\hline Groups & $\mathrm{n}$ & $\begin{array}{c}\text { Age } \\
(\text { Year })\end{array}$ & $\begin{array}{c}\text { Body } \\
\text { weight } \\
\mathbf{( K g )}\end{array}$ & $\begin{array}{c}\text { BMI } \\
\left(\mathbf{k g} / \mathbf{m}^{\mathbf{2}}\right)\end{array}$ \\
\hline $\mathbf{A}$ & \multirow{2}{*}{30} & $49.17 \pm$ & $55.53 \pm$ & $21.73 \pm 1.56$ \\
& & 7.02 & 6.32 & $(18.89-$ \\
& & $(40-60)$ & $(46-70)$ & $23.81)$ \\
B & \multirow{2}{*}{30} & $51.43 \pm$ & $55.87 \pm$ & $23.15 \pm 1.01$ \\
& & 6.07 & 6.46 & $(20.57-$ \\
& & $(40-60)$ & $(50-70)$ & $24.44)$ \\
\hline
\end{tabular}

Group A: Comparison group (Healthy non-diabetic subjects)

Group B: Study group (Diabetic patients)

$\mathrm{n}=$ Total number of subjects

Table II: Fasting blood glucose and $\mathrm{HbA}_{1 \mathrm{c}}$ levels in different groups $(n=60)$

\begin{tabular}{lccl}
\hline Groups & $\mathrm{n}$ & $\begin{array}{l}\text { Fasting blood glucose } \\
\mathrm{mmol} / \mathrm{L}\end{array}$ & $\begin{array}{l}\mathrm{Hb}_{1 \mathrm{c}} \\
\%\end{array}$ \\
\hline $\mathrm{A}$ & 30 & $5.08 \pm 0.64$ & $5.04 \pm 0.42$ \\
$\mathrm{~B}_{1}$ & 17 & $8.53 \pm 1.16$ & $7.17 \pm 0.63$ \\
$\mathrm{~B}_{2}$ & 13 & $5.65 \pm 1.08$ & $5.62 \pm 0.51$ \\
& & & \\
\hline
\end{tabular}

Statistical analysis

\begin{tabular}{lll}
\hline Groups & $\begin{array}{l}\text { Fasting blood } \\
\text { glucose }\end{array}$ & HbA $_{\mathbf{1 c}}$ \\
\hline $\mathrm{A}$ vs $\mathrm{B}_{1}$ vs $\mathrm{B}_{2}$ & $<0.001^{* * *}$ & $<0.001^{* * *}$ \\
$\mathrm{~A}$ vs $\mathrm{B}_{1}$ & $<0.001^{* * *}$ & $<0.001^{* * *}$ \\
$\mathrm{~A}$ vs $\mathrm{B}_{2}$ & $0.048^{*}$ & $<0.003^{* *}$ \\
$\mathrm{~B}_{1}$ vs $\mathrm{B}_{2}$ & $<0.001^{* * *}$ & $<0.001^{* * *}$ \\
\hline Group A: Comparison group (Healthy non- diabetic subjects) \\
Group $\mathrm{B}_{1}$ : Uncontrolled diabetic patients \\
Group $\mathrm{B}_{2}$ : Controlled diabetic patients \\
$* * *=$ Significant at $p<0.001, * *=$ Significant at $p<0.01$, \\
$*=$ Significant at $p \leq 0.05$ \\
$\mathrm{n}=$ Total number of subjects
\end{tabular}

In this study, the mean serum TSH level was significantly $(p<0.001, \quad p \leq 0.05)$ higher in uncontrolled and controlled diabetic patients than that of non-diabetic subjects and it was also significantly $(p<0.01)$ higher in uncontrolled diabetic patients as compared to controlled diabetic patients. On the other hand, the mean serum $\mathrm{FT}_{4}$ level was significantly $(p<0.01$, $p \leq 0.05)$ lower in uncontrolled diabetic patients than that of non-diabetic subjects and controlled diabetic patients. This level was lower in controlled diabetic patients than that of nondiabetic subjects but the difference was not statistically significant. However, the mean serum $\mathrm{FT}_{3}$ level was significantly $(p \leq 0.05)$ lower in uncontrolled diabetic patients in comparison to that of non-diabetic subjects. $\mathrm{FT}_{3}$ level was lower in controlled diabetic patients than that of non-diabetic subjects but the difference was not statistically significant. Again, this level was lower in uncontrolled diabetic patients than that of controlled diabetic patients but the difference was not statistically significant (table III). Moreover, $\mathrm{HbAlc}$ found positively correlated with serum TSH level and negatively correlated with serum $\mathrm{FT}_{4} \& \mathrm{FT}_{3}$ level (figure 1, 2, \& 3).

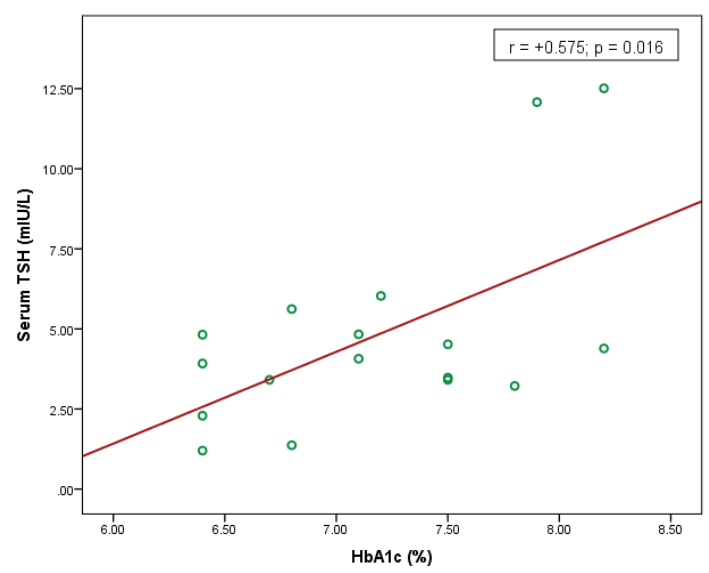

Figure 1: Correlation of $\mathrm{HbAlc}$ with serum $\mathrm{TSH}$ in uncontrolled diabetic patients

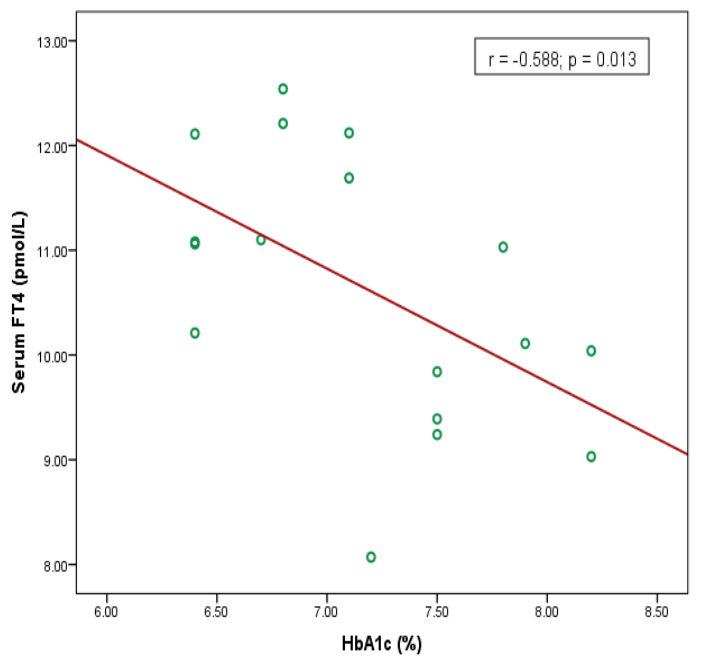

Figure 2: Correlation of $\mathrm{HbAlc}$ with serum $\mathrm{FT}_{4}$ in uncontrolled diabetic patients 
Table III: Serum TSH, $\mathrm{FT}_{4}$ and $\mathrm{FT}_{3}$ levels in different groups $(\mathrm{n}=60)$

\begin{tabular}{lllll}
\hline Groups & $\mathbf{n}$ & $\begin{array}{l}\text { TSH } \\
(\mathrm{mIU} / \mathrm{L})\end{array}$ & $\begin{array}{l}\mathrm{FT}_{4} \\
(\mathrm{pmol} / \mathrm{L})\end{array}$ & $\begin{array}{l}\mathbf{F T}_{3} \\
(\mathrm{pmol} / \mathrm{L})\end{array}$ \\
\hline $\mathrm{A}$ & 30 & $1.53 \pm 0.77$ & $13.29 \pm 3.06$ & $4.18 \pm 0.82$ \\
$\mathrm{~B}_{1}$ & 17 & $4.77 \pm 3.12$ & $10.64 \pm 1.29$ & $3.66 \pm 0.78$ \\
$\mathrm{~B}_{2}$ & 13 & $2.52 \pm 1.46$ & $12.21 \pm 2.21$ & $3.74 \pm 0.80$
\end{tabular}

\begin{tabular}{|c|c|c|c|}
\hline Groups & TSH & $\mathbf{F T}_{4}$ & $\mathrm{FT}_{3}$ \\
\hline $\mathrm{A}$ vs $B_{1} v s$ & $<0.001^{* * *}$ & $0.004^{* *}$ & $0.069^{\mathrm{ns}}$ \\
\hline $\begin{array}{l}\mathrm{B}_{2} \\
\mathrm{~A} \text { vs } \mathrm{B}_{1}\end{array}$ & $<0.001^{* * *}$ & $0.003^{* *}$ & $0.047^{*}$ \\
\hline $\mathrm{A}$ vs $\mathrm{B}_{2}$ & $0.046^{*}$ & $0.590^{\mathrm{ns}}$ & $0.313^{\text {ns }}$ \\
\hline$B_{1} v_{s} B_{2}$ & $0.005^{* *}$ & $0.041^{*}$ & $1.000^{\mathrm{ns}}$ \\
\hline
\end{tabular}

Group A: Comparison group (Healthy non- diabetic subjects) Group $\mathrm{B}_{1}$ : Uncontrolled Diabetic patients

Group $\mathrm{B}_{2}$ : Controlled Diabetic patients

$* * *=$ Significant at $\mathrm{p}<0.001, * *=$ Significant at $\mathrm{p}<0.01, *=$ Significant at $\mathrm{p} \leq 0.05$

$\mathrm{ns}=$ not significant $\mathrm{n}=$ total number of subjects

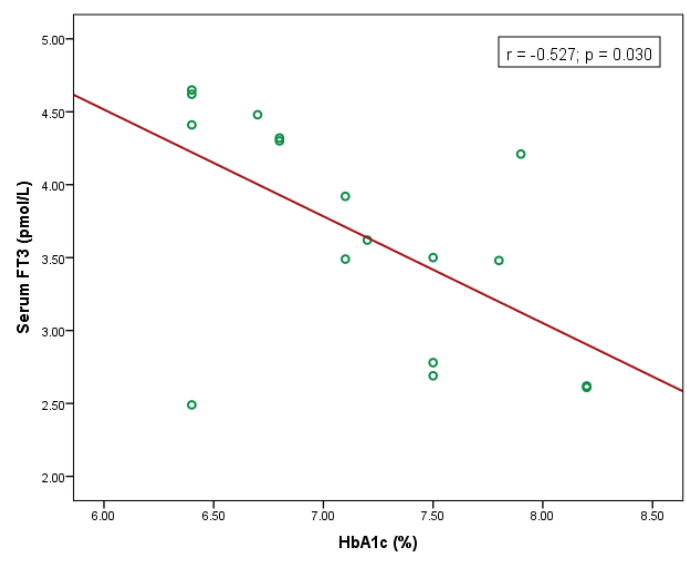

Figure 3: Correlation of $\mathrm{HbA} 1 \mathrm{c}$ with serum $\mathrm{FT}_{3}$ in uncontrolled diabetic patients

Again, in this study, among the uncontrolled diabetic patients, $70.6 \%$ were euthyroid, $11.8 \%$ were hypothyroid and $17.7 \%$ were subclinical hypothyroid (figure 4).

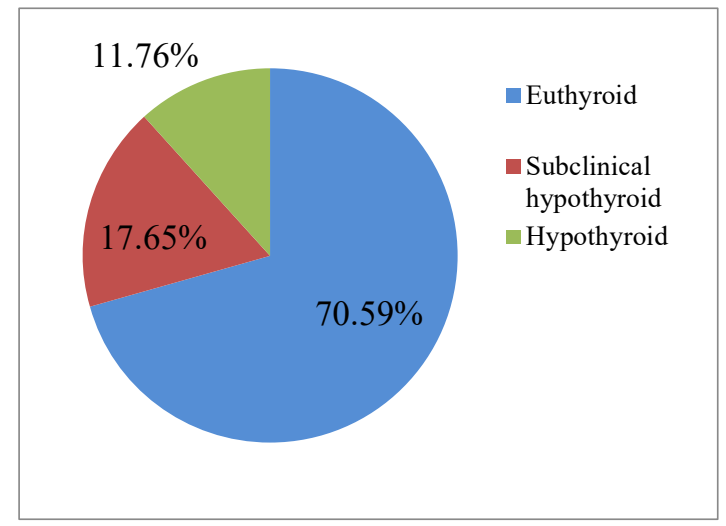

Figure 4: Distribution of thyroid dysfunction in uncontrolled diabetic patients $(\mathrm{n}=17)$

\section{Discussion}

This study observed thyroid function status in uncontrolled and controlled type 2 diabetic patients by measuring thyroid hormone levels. HbAlc level was also estimated to find out its level on diabetic patients and to correlate them with serum TSH, $\mathrm{FT}_{4}$ and $\mathrm{FT}_{3}$ levels. Results of this study showed serum TSH level was significantly higher in uncontrolled diabetic patients than that of controlled diabetic patients. This result agrees to other researchers. ${ }^{17}$ The exact mechanism that was involved in high TSH level in type 2 diabetic patients was not yet clearly established. However, several investigators of different countries proposed various suggestions on this aspect. Some researchers reported that metabolic control affects the hypothalamo-pituitary-thyroid (HPT) axis and metabolic de-compensation leads to impairment of TSH secretion and TSH response to TRH stimulation was blunted in poorly controlled diabetic patients that cause hypothyroidism in type 2 diabetic patients. ${ }^{16,17}$

Whereas the mean serum $\mathrm{FT}_{4}$ level was significantly lower in uncontrolled diabetic patients than that of controlled diabetic patients. These findings were consistent with that of some other researchers of different countries. ${ }^{17}$ Again, the mean serum $\mathrm{FT}_{3}$ level was non-significantly lower in uncontrolled diabetic patients than that of controlled diabetic patients. Similar finding was observed by Gursoy et al. ${ }^{17}$ On the other hand, some researchers found significantly lower serum $\mathrm{FT}_{3}$ level in uncontrolled diabetic patients than that of controlled diabetic patients. ${ }^{15} \mathrm{~T}_{4^{-}}$ 5 'deiodinase enzyme is responsible for deiodination of $T_{4}$ to $T_{3}{ }^{26}$ This enzyme activity was decreased in streptozotocin induced diabetic rats that catalyzes peripheral deiodination of $\mathrm{T}_{4}$ to $\mathrm{T}_{3}$ and produces low $\mathrm{T}_{3}$ state. ${ }^{20}$ Pittman et al reported that, reduced level of tissue glutathione is responsible for lowering deiodination in streptozotocin induced diabetic rats. ${ }^{27}$ Moreover, thyroid hormone binding inhibitor (THBI), inhibitor of extrathyroidal conversion (IEC) of thyroxine to triiodothyronine and free fatty acid (FFA) are responsible for abnormal thyroid hormone level in uncontrolled diabetic patients. ${ }^{28}$

In the present study, lower levels of thyroid hormones may be due to poor glycemic control. The significant negative correlation of $\mathrm{HbA}_{1 \mathrm{c}}$ level with $\mathrm{FT}_{3}$ and $\mathrm{FT}_{4}$ levels in uncontrolled diabetic patients are in favor of this statement. Again, serum thyroid stimulating hormone level was found significantly higher in uncontrolled 
diabetic patients than controlled diabetic patients. This may be due to negative feedback regulation resulting in increased TSH secretion from the anterior pituitary gland. The positive correlation of serum TSH level with $\mathrm{HbA}_{1 \mathrm{c}}$ of the subjects further supports these findings.

\section{Conclusion}

Based on the results of this study, it can be concluded that, hypothyroidism occurs in type 2 diabetic patients which was found only in uncontrolled diabetic patients and this may be due to their poor glycaemic control.

\section{Acknowledgement}

The authors do acknowledge gratefully to all the faculty members of the Department of Physiology, SSMC for their active support and offer special thanks to all the study population for their kind cooperation indeed

Conflict of interest: The authors declared no conflict of interest.

\section{Funding: None}

Submitted: $21^{\text {th }}$ October, 2019

Final revision received: $15^{\text {th }}$ March, 2020

Accepted: $19^{\text {th }}$ March, 2020

Published online: $1^{\text {st }}$ April, 2020

\section{References}

1. Vasudevan DM, Text book of Biochemistry for medical students, $6^{\text {th }}$ edn. 2011: 285-86

2. Hall, J.E., Insulin, Glucagon and Diabetes Mellitus, Text book of Medical Physiology, $13^{\text {th }}$ ed, Elsveier Private Limited, New Delhi. 2016: 994.

3. Wild S, Roglic G, Green A, Sicree R. and King H. Global prevalence of diabetes. Diabetes Care. 2004; 27; 1047-53.

DOI : 10.2337/diacare.27.5.1047

4. Zimmet P, Alberti KG, Shaw J. Global and societal implications of the diabetes epidemic. Nature. 2001; 414: 499-518.

DOI : $10.2337 / 10.1038 / 414782 \mathrm{a}$

5. Pearson ER, McCrimmon RJ. Diabetes Mellitus In: Walker BR, College NR, Ralston SH, Penman ID. Davidson's Principles \& Practice of Medicine, $22^{\text {nd }}$ ed., Elsevier limited, London. pp. 826.

6. Karar T, Alhammad RIS, Fattah MA, Alanazi A, Qureshi S, Relation between glycosylated hemoglobin and lipid and thyroid hormone among patients with type 2 diabetes mellitus at King abdulaziz Medical City, Riyadh. J Nat Sci Biol Med. 2015; 6: S75-S79.

DOI : $10.4103 / 0976-9668.166091$
7. Tunbridge WMG, Evered DC, Hall R, Appleton $\mathrm{D}$, Brewis M, Clark F et al. The Spectrum of thyroid disease in a community: The Whickham Survey. Clinical Endocrinology. 1977;7:481-93. DOI : 10.1111/j.1365-2265.1977.tb01340.x

8. Ghazali SM, Abbiyesuku FM. Thyroid dysfunction in type 2 diabetes seen at the university college hospital, Ibadan, Nigeria, Nij. J. Physiol. Sci. 2010;25: 173-79.

9. Umpierrez GE, Latif KA, Murphy MB, Lambert HC, Stentz F, Bush A, 'Thyroid dysfunction in patients with type 1 diabetes. Diabetes Care. 2015;26:1181-85.

10. Chen G, Juan W, Yinghua L. Associations between cardiovascular risk, insulin resistance, $\beta$ cell function and thyroid dysfunction: a cross sectional study in She ethnic minority group of Fujian Province in China. Euro J Endocrinal. 2010; $163: 775-82$.

DOI: 10.1530/EJE-10-0710

11. Udiong CEJ, Udoh E, Etukudoh ME. Evaluation of thyroid function in diabetes mellitus in Calabar, Nigeria, Indian Journal of Clinical Biochemistry. 2007;22:74-78.

DOI : 10.1007/BF02913318

12. Vij V, Chitnis P, Gupta VK, Evaluation of thyroid dysfunction among type 2 diabetic patients, International Journal of Pharmacy and Biological Sciences. 2012;2: 150-55.

13. Mamun MS, Thyroid hormonal status in newly diagnosed type 2 diabetes mellitus, M.Phil thesis. Bangabandhu Seikh Mujib Medical University. 2017; 20: 27-31

DOI: 10.3329/bjnm.v20i1.36851

14. Makandar A, Sonagra AD, Shafi N. Study of thyroid function in type 2 diabetic and non-diabetic population, International Journal of Medical Science and Public Health. 2015; 4; 769-72.

15. Schlienger JL, Anceau A, Chabrier G, North ML, Stephan F. Effect of diabetic control on the level of circulating thyroid hormones, Diabetologia. 1982; 22: 486-88.

DOI: $10.1007 / \mathrm{bf00282596}$

16. Bartalena L, Cossu E, Grasso L, Velluzzi F, Loviselli A, Cirillo R, Martino E. Relationship etween nocturnal serum thyrotropin peak and metabolic control in diabetic patients, The Journal of Clinical Endocrinology \& Metabolism. 1993;76: 983-87.

DOI : $10.1210 /$ jcem.76.4.8473414

17. Gursoy N, Tuncel E, Erturk E, Imamoglu S, Annik A. The relationship between the glycemic control and the hypothalamus-pituitary-thyroid axis in diabetic patients. Turkish Journal of Endocrinology and Metabolism, 1999;4:163-68. 
18. Rezzonico J, Rezzonico M, Pusiol E, Pitoia F, Niepomniszcze $\mathrm{H}$ Introducing the thyroid gland as another victim of the insulin resistance syndrome. Thyroid. 2008; 18: 461-64.

DOI : $10.1089 /$ thy.2007.0223

19. Bestetti GE, Reymond MJ, Perrin IV, Kniel PC, Lemarchand-Béraud T, Rossi GL. Thyroid and pituitary secretary disorders in streptozotocindiabetic rats are associated with severe structural changes of these glands. Virchows Archiv B.1987;53:69-78

DOI: $10.1007 / \mathrm{bf} 02890227$

20. Gavin LA, McMahon FA, Moeller AM. The mechanism of impaired $\mathrm{T}_{3}$ production from $\mathrm{T}_{4}$ in diabetes, Diabetes. 1981;30: 694-99.

DOI : $10.2337 /$ diab.30.8.694

21. Sahu S, Dutta SK, Kuiri SS, Nandi MM, Kabiraj $P$, De U. Prevalence of thyroid dysfunction in patients with type 2diabetes mellitus and its correlation with insulin resistance and serum markers for autoimmune thyroiditis. Asian Journal of Medical Sciences. 1981; 6: 33-38.

DOI : 10.3126/ajms.v6i6.12603

22. Jain G, Marwaha TS, Khurana A, Dhoat PS. Prevalence of thyroid disorders in patients of type 2 diabetes mellitus. IJMDS. 2013;2:153-61.

23. Galag SC, Rajalakshmi R, Srinath KM, Madhu B. Subclinical hypothyroidism in type 2 diabetes mellitus patients in a tertiary care hospital, Mysore. Indian J Physiol Pharmacol. 2016;60:255-9.

24. Taksali R, Bindu M, Mulay S. Evaluation of thyroid dysfunction in type II diabetes mellitus: a case control study, International Journal of Current Medical and Applied Sciences. 2013; 1:16-20.

25. Chen HS, Wu TE, Jap TS, Lu RA, Wang ML, Chen RL et al. Subclinical hypothyroidism is a risk factor for nephropathy and cardiovascular diseases in type 2 diabetic patients. Diabet Med. 2013; 24:1336-44. DOI: $10.1111 / \mathrm{j} .1464-5491.2007 .02270 . \mathrm{x}$

26. Barrett KE, Barman SM, Boitano S, Brooks HL. The Thyroid Gland, Ganong's Review of Medical Physiology, 24 ${ }^{\text {th }}$ ed., Tata McGraw-Hill companies. Inc. New York. 2012. p339-51.

27. Pittman CS, Lindsay RH, Senga O, Chambers, Jr $\mathrm{JB}$, Hill Jr, JB. The effects of diabetes mellitus on the 3,5,3-triiodithyronine production. Life Sciences. 1981; 28:15-16. DOI: 10.1016/0024-3205 (81)90338-6

28. Suzuki Y, Nanno M, Gemma R, Tanaka I, Taminato $\mathrm{T}$, Yoshimi $\mathrm{T}$. The mechanism of thyroid hormone abnormalities in patients with diabetes mellitus. 1994;70:465-70.

DOI: $10.1507 /$ endocrine1927.70.4_465 